УДК 618.11-006.6-085.28.036.8

DOI 10.11603/2414-4533.2016.3.6789

( В В. Г. ДУБІНІНА, О. В. ЛУК'ЯНЧУК, А. І. РИБІН, О. В. КУЗНЕЦОВА, А. О. МАШУКОВ

Одеський національний медичний університет

\title{
Оптимізація хірургічного лікування хворих на рак яечників
}

\author{
V. H. DUBININA, O. V. LUKYANCHUK, A. I. RYBIN, O. V. KUZNETSOVA, A. O. MASHUKOV \\ Odesa State Medical University
}

\section{OPTIMIZATION OF SURGICAL TREATMENT OF PATIENTS WITH OVARIAN CANCER}

\begin{abstract}
У статті автори показують власний досвід застосування методики інтраопераційної гіпертермічної інтраперитонеальної хіміоперфузії (НYРЕС) у хворих на розповсюджений рак яєчників. На підставі аналізу 25 клінічних випадків автори зазначають, що розроблена методика $є$ інноваційною та ефективною. На фоні багатьох переваг методу не було виявлено відмінностей в токсичності застосовуваних препаратів між традиційною терапією раку яєчників і вдосконаленою методикою із застосуванням НУРЕС. Автори вважають, що гіпертермія є одним із можливих механізмів подолання резистентності до платини.

In the article the authors show their own experience with the technique of intraoperative intraperitoneal hypertermic intrapentoneal chemioperfusion (HYPEC) in patients with disseminated ovarian cancer. Based on analysis of 25 clinical cases, the authors note that the technique is innovative and effective. Having the many advantages of the method the authors found no difference in the toxicity of the drugs between traditional and advanced ovarian cancer treatment method using HYPEC. The authors consider, that hyperthermia is one of the possible mechanisms for overcoming resistance to platinum.
\end{abstract}

Постановка проблеми і аналіз останніх досліджень та публікацій. Рак яєчників (РЯ) на сьогодні є найбільш агресивною пухлиною жіночої статевої сфери, що зумовлено вкрай низькою 5-річною виживаністю хворих із даною онкологічною патологією, яка не перевищує 25-29 \%. Незважаючи на відносно стабільні показники захворюваності на РЯ, за показниками смертності РЯ випереджає рак тіла і шийки матки, займаючи 5-те місце серед причин смерті від усіх пухлин у жінок. За даними Міжнародного агентства з вивчення раку, в світі щорічно реєструють 165000 нових випадків РЯ, і більше 100 тис. жінок гинуть від злоякісних новоутворень яєчників. Летальність хворих на РЯ на першому році після встановлення діагнозу становить 35 \%. Дані обставини пояснюються асимптоматичним перебігом РЯ на ранніх стадіях, що призводить до пізньої діагностики захворювання, коли виконання радикального операційного втручання не є можливим [1, 2, 5, 8].

На сьогодні “золотим стандартом” лікування РЯ стадій III A-III C $€$ операційне втручання $з$ подальшим курсом післяопераційної хіміотерапії. Незважаючи на те, що РЯ належить до числа найбільш чутливих до хіміотерапії пухлин, до 40 \% пацієнток із даним захворюванням $€$ первинно-резистентними до платинової хіміотерапії [1, 3, 4]. На- віть при виконанні оптимальної циторедуктивної операції і надалі призначення хіміотерапії препаратами платини (хіміотерапія першої лінії) з досягненням ефекту повної регресії і нормалізації рівнів пухлинних маркерів 5-річна виживаність хворих на РЯ III стадії становить 20-25 \%, а IV стадії - не перевищує $10 \%[9,10]$. Це означає, що, незважаючи на відсутність клінічних ознак захворювання, у більшості хворих у перші 2-3 роки після закінчення хіміотерапії першої лінії слід очікувати прогресування захворювання. Частота об'єктивного ефекту коливається в межах 10-25 \%, а медіана тривалості життя становить 7-18 місяців. Більшість вітчизняних і зарубіжних авторів сходиться на думці, що максимально можлива циторедукція $є$ основним аспектом успішного лікування пацієнток з РЯ [1, 3, $4,7,11]$. Таким чином, удосконалення методик хірургічного та комбінованого лікування хворих на РЯ є надзвичайно актуальним і насущним завданням сучасної онкогінекології.

Мета роботи: оцінка ефективності використання гіпертермічної інтраперитонеальної хіміотерапії і циторедуктивної хірургії в лікуванні хворих на РЯ.

Матеріали і методи. Протягом 2015-2016 рр. на базах кафедри онкології з курсом промене- 
вої діагностики, терапії та радіаційної медицини Одеського національного медичного університету виконано 25 операційних втручань із застосуванням гіпертермічної інтраперитонеальної хіміотерапії (НYРЕС). У всіх хворих було діагностовано серозну аденокарциному яєчників III A-III C стадій. Вік пацієнток коливався від 21 до 59 років, обсяг операційного втручання було оціненой як субоптимальну циторедуктивну операцію. Порівняльний аналіз проводили з 25 пацієнтками (група контролю) з РЯ аналогічних стадій після операційного втручання без застосування методики НYРЕС. Надалі пацієнтки обох груп отримували 4-6 курсів ад’ювантної ПХТ. Процедуру НҮРЕС виконували за допомогою апарата Performer LRT. Performer LRT - це багатофункціональна система для проведення місцевої локальної спеціалізованої хіміотерапії, орієнтована на підтримку декількох режимів терапії, основаних на екстракорпоральному циркулюванні крові/рідин. Хіміотерапевтичні препарати, за визначенням, є токсичними, і їх використання у високих концентраціях може бути пов'язано з появою побічних ефектів терапії. Локальна регіональна хіміотерапія дозволяє створити набагато вищі цільові концентрації в злоякісному вогнищі. Єдине “але”: препарати повинні бути захищені від негайного вимивання із зони їх локальної активності. Циркуляторні параметри (температура, об’єм, швидкість інфузії) можна легко відкоригувати і моніторувати в онлайн режимі (рис.1).

Процедуру внутрішньочеревної гіпертермічної хіміоперфузії виконують таким чином (рис. 2). Даний вид лікування полягає в перфузуванні по-

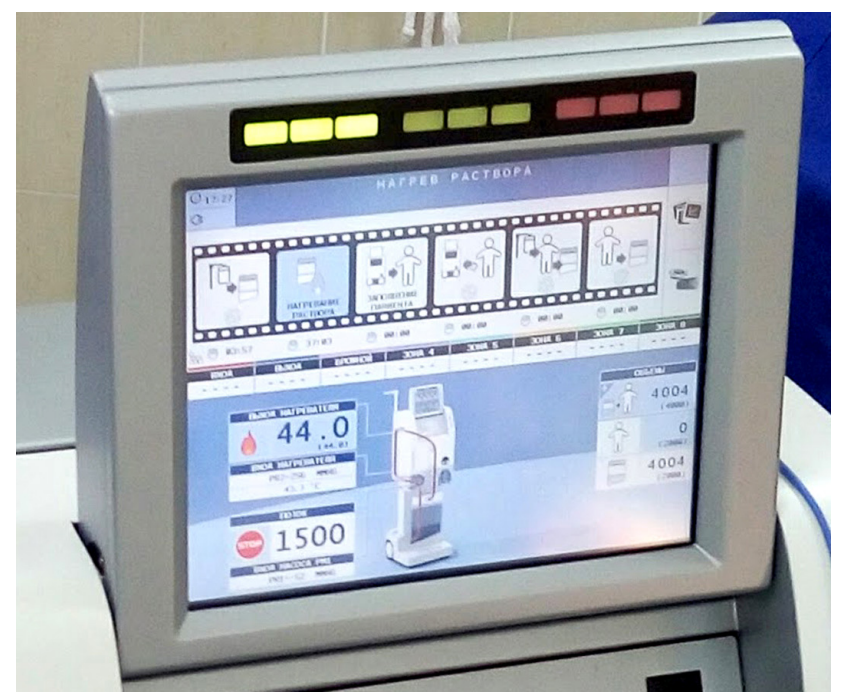

Рис. 1. Показники роботи системи: цільова температура $44{ }^{\circ} \mathrm{C}$, обсяг 1500,0 мл, II фаза роботи (шестисантиметрова лінійка у верхній частині монітора) - нагрівання розчину.

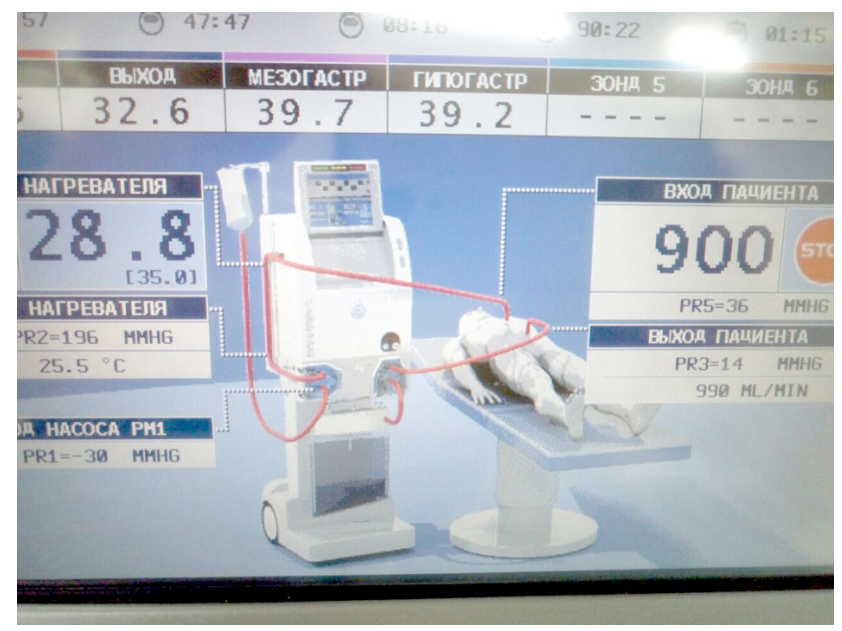

Рис. 2. Схема виконання процедури НYРЕС.

рожнини живота хіміотерапевтичним агентом (зазвичай цисплатин або мітоміцин С) при температурі $42,5{ }^{\circ} \mathrm{C}$ і усередненій швидкості потоку 800/900 мл/хв протягом 60-90 хв. Лікування призначають після циторедуктивної хірургічної операції з приводу перитонеального канцероматозу або саркоматозу, викликаних гастроінтестинальною карциномою або карциномою яєчників, псевдоміксомою, перитонеальною мезотеліомою [10]. Іншими можливими режимами $є$ ізольована гіпертермія кінцівок $\left(41,5^{\circ} \mathrm{C}, 60-90\right.$ хв) і гемофільтрація (нормотемпературна, 20 хв). Після хірургічного видалення якомога більшого обсягу пухлинної тканини п’ять силіконових трубок поміщаються в черевну порожнину (рис. 3); температурні датчи-

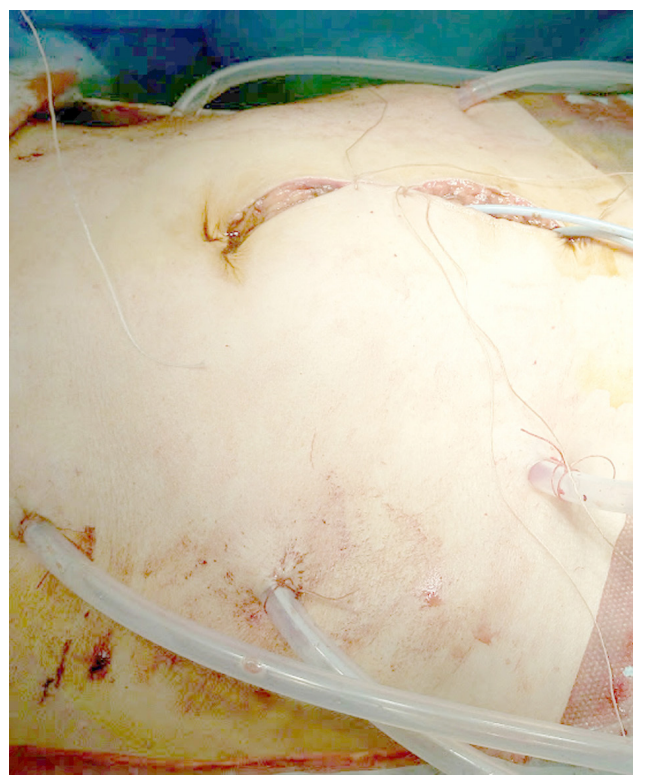

Рис. 3. Вид операційного поля після установки 5 промивних ПХВ дренажів та інтраабдомінальних температурних зондів. 
ки розміщуються в черевній порожнині вище мезоколона і в тазі, операційну рану зашивають остаточними швами. Процедуру НYРЕС виконують на апараті RAND Performer (Модена, Італія) за допомогою двох попм (насоси, які нагнітають і евакуюють рідину з черевної порожнини), температурного охолоджувача і стерильного закритого контуру. Після досягнення інтраабдомінальної температури як мінімум $41{ }^{\circ} \mathrm{C}$, мітоміцин С - 25 мг/мл, цисплатин - 100 мг/мл розчиняють в 5000,0 мл перфузату, який циркулює зі швидкістю 700-800 мл/ хв протягом 60 хв. Середній обсяг перфузату, що міститься в черевній порожнині, щомиті становить близько 3000 мл.

Інтраабдомінальна температура коливається від 41 до $43{ }^{\circ} \mathrm{C}$. Фаза охолодження черевної порожнини і фаза промивання від хіміопрепаратів займають максимально до 5-10 хв. Пацієнтку переводять на одну добу в реанімаційне відділення для проведення інтенсивної терапії та спостереження. Всім пацієнткам інтраопераційно визначали індекс перитонеального канцероматозу, а також індекс повноти циторедукції [10]. Критеріями ефективності проведеного лікування були показники якості життя та ступеня токсичності препаратів.

Якість життя хворих оцінювали за допомогою методики оцінки якості життя Medical Outcomes Study 36-Item Short Form Health Survey (SF-36) [12]. Обробку даних проводили за допомогою статистичної програми “Біостат”. Побічні ефекти комбінації лікування оцінювали окремо в розрахунку на кількість хворих та кількість курсів хіміотерапії [5].

Результати досліджень та їх обговорення. 3 огляду на рандомізований відбір пацієнток у досліджувані групи, слід зазначити, що з 25 пацієнток основної групи 17 хворих були з III C стадією захворювання, 5 жінок мали III А стадію й у 3 пацієнток було виявлено III В стадію раку яєчників. Розподіл пацієнток контрольної групи по стадіях був таким. Із 25 пацієнток другої групи
13 хворих були з III С стадією захворювання, 12 жінок мали III А стадію й у 2 пацієнток було виявлено III В стадію раку яєчників. Індекс перитонеального канцероматозу в основній групи був LS-1 (28,0 \%) та LS-2 (72,0 \%). У групі контролю аналогічний показник вірогідно не відрізнявся та склав 36,0 \% (LS-1) і 64,0 \% (LS-2). Індекс повноти циторедукції також не відрізнявся між групами і склав в основній групі СС-1 (28,0 \%) та CC-2 (72,0 \%), не відрізняючись від аналогічного показника в контрольній групі (СС-1 - 36,0 \%, СС-2 - 64,0 \%).

Порівняльний аналіз показників якості життя у досліджуваних групах через 6 місяців після закінчення лікування не показав статистично достовірних розходжень (табл. 1).

Слід зазначити, що в основній групі ми не виявили жодного випадку алергійних або побічних реакцій у пацієнток основної групи. У 9 (36,0%) хворих першої групи протягом першої доби спостереження після проведення НYРЕС було виявлено гіпертермічну реакцію (підвищення температури тіла до 38,0 ㄷ протягом 6-7 год), яку купірували прийманням нестероїдних протизапальних препаратів. Необхідно також підкреслити, що 5 (20,0 \%) пацієнток скаржилися на почуття болю i дискомфорту в ділянці введення промивних дренажів.

Порівняльний аналіз ступеня токсичності застосовуваних хіміопрепаратів в обох групах показав таке (табл. 2, 3).

Отримані результати свідчать, що ступінь гематологічної токсичності хіміопрепаратів вірогідно не відрізнявся у пацієнток обох груп. Стосовно гастроінтестинальної токсичності ми не отримали вірогідної різниці між групами, які вивчали. Необхідно підкреслити, що відсоток розвитку стоматиту також вірогідно не відрізнявся між групами.

Середня тривалість післяопераційного перебування хворих в стаціонарі склала 9,1 ліжко-дня і достовірно не відрізнялась від такої у хворих 3 РЯ без проведення НYРЕС.

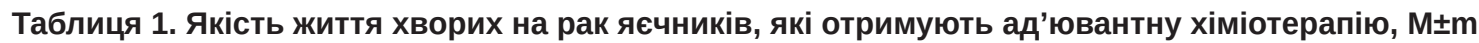

\begin{tabular}{|l|c|c|}
\hline \multicolumn{1}{|c|}{ Шкала SF-36 } & Основна група (n=25) & Контрольна група (n=25) \\
\hline Фізична активність & $34,08 \pm 21,14$ & $31,88 \pm 19,44$ \\
\hline Рольові обмеження внаслідок фізичних проблем & $21,42 \pm 13,43$ & $21,01 \pm 14,23$ \\
\hline Фізичний біль & $46,29 \pm 16,23$ & $41,27 \pm 20,11$ \\
\hline Сприйняття загального стану здоров’я & $35,33 \pm 14,76$ & $33,72 \pm 23,27$ \\
\hline Енергійність (життєздатність) & $43,85 \pm 24,16$ & $44,25 \pm 34,26$ \\
\hline Соціальне функціонування & $65,42 \pm 26,16$ & $63,12 \pm 22,39$ \\
\hline Рольові обмеження внаслідок емоційних проблем & $42,11 \pm 15,46$ & $44,25 \pm 17,24$ \\
\hline Психічне здоров’я & $59,32 \pm 22,26$ & $59,32 \pm 22,26$ \\
\hline
\end{tabular}


Таблиця 2. Токсичність комбінації хіміопрепаратів в основній групі

\begin{tabular}{|c|c|c|c|c|c|}
\hline \multirow{2}{*}{ Вид токсичності } & \multicolumn{4}{|c|}{ Ступінь токсичності } & \multirow{2}{*}{ Всього, \% } \\
\hline & I & II & III & IV & \\
\hline Лейкопенія & $8(32,0 \%)$ & $5(20,0 \%)$ & $4(16,0 \%)$ & $1(4,0 \%)$ & $72,0 \%$ \\
\hline Нейтропенія & $7(28,0 \%)$ & $4(16,0 \%)$ & $4(16,0 \%)$ & - & $60,0 \%$ \\
\hline Анемія & $11(44,0 \%)$ & $4(16,0 \%)$ & $1(4,0 \%)$ & - & $74,0 \%$ \\
\hline Тромбоцитопенія & $2(8,0 \%)$ & 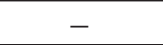 & - & - & $8,0 \%$ \\
\hline Нудота & $6(24,0 \%)$ & $5(20,0 \%)$ & $5(20,0 \%)$ & 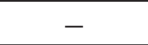 & $64,0 \%$ \\
\hline Блювання & $9(36,0 \%)$ & $3(12,0 \%)$ & $3(12,0 \%)$ & - & $60,0 \%$ \\
\hline Діарея & $1(4,0 \%)$ & - & - & - & $4,0 \%$ \\
\hline Стоматити & $3(12,0 \%)$ & $1(4,0 \%)$ & $1(4,0 \%)$ & - & $20,0 \%$ \\
\hline
\end{tabular}

Таблиця 3. Токсичність комбінації хіміопрепаратів у групі контролю

\begin{tabular}{||l|c|c|c|c|c||}
\hline \multirow{2}{*}{ Вид токсичності } & \multicolumn{4}{|c||}{ Ступінь токсичності } & \multirow{2}{*}{ Всього, \% } \\
\cline { 1 - 5 } & $\mathrm{I}$ & $\mathrm{II}$ & $\mathrm{III}$ & $\mathrm{IV}$ & \\
\hline Лейкопенія & $10(40 \%)$ & $8(32,0 \%)$ & $1(4,0 \%)$ & $1(4,0 \%)$ & $80,0 \%$ \\
\hline Нейтропенія & $11(44,0 \%)$ & $4(16,0 \%)$ & $2(8,0 \%)$ & $1(4,0 \%)$ & $72,0 \%$ \\
\hline Анемія & $7(28,0 \%)$ & $6(24,0 \%)$ & $4(16,0 \%)$ & - & $68,0 \%$ \\
\hline Тромбоцитопенія & $4(16,0 \%)$ & - & - & - & $16,0 \%$ \\
\hline Нудота & $7(28,0 \%)$ & $4(16,0 \%)$ & $4(16,0 \%)$ & - & $60,0 \%$ \\
\hline Блювання & $10(40, \%)$ & $4(16,0 \%)$ & $1(4,0 \%)$ & - & $60,0 \%$ \\
\hline Діарея & $3(12,0 \%)$ & - & - & - & $12,0 \%$ \\
\hline Стоматити & $2(8,0 \%)$ & $4(16,0 \%)$ & $1(4,0 \%)$ & - & $28,0 \%$ \\
\hline \hline
\end{tabular}

Висновки. Методика застосування хіміотерапії у пацієнток з поширеним РЯ (стадії III A - III C) у вигляді НҮРЕС $є$ інноваційною та ефективною. Крім зміни шляху введення і часу застосування (під час операції або в ранньому післяопераційному періоді протягом перших 5 днів), слід зазначити, що гіпертермія, на думку ряду авторів, є одним із механізмів подолання можливої плати-

\section{СПИСОК ЛІТЕРАТУРИ}

1. Активность белка р53 у больных раком яичников в зависимости от чувствительности к препаратам платины / В. Г. Дубинина, А. И. Рыбин, О. В. Кузнецова, О. Н. Морозюк // Клин. онкол. - 2015. - № 4 (20). - С. 91-94.

2. Онкогінекологія : навч. посіб. / [В. Г. Дубініна, А. І. Рибін, Н. В. Тюєва, О. В. Лук’янчук] ; за ред. В. Г. Дубініної. Одеса, ОНМедУ, 2013. - 200 с.

3. Рак яичников: концепция патогенеза и принципы терапии / Л. А. Ашрафян, В. И. Киселев, Е. Л. Муйжнек [и др.] // Онкология. Журнал им. П. А. Герцена. - 2015. - Т. 4, № 3. С. $73-81$.

4. Свинцицкий В. С. Серозный рак яичников: тестирование мутаций генов BRCA1 и BRCA2 в Украине / В. С. Свинцицкий // Евразийский онкологический журнал (прилож.). 2015. - С. 79-82.

5. Халафян A. A. Statistica 6. Статистический анализ данных / А. А. Халафян. - М. : ООО “Бином-Пресс”, 2008. - 512 с.

6. A metabolomic approach to identifying platinum resistance in ovarian cancer / L. M. Poisson, A. Munkarah, H. Madi [et al.] // J. Ovarian Res. - 2015. - Vol. 8 - P. 13.

7. Developing the World Health Organization Disability норезистентності. Однак ми вважаємо, що сприятливий прогноз у пацієнток з РЯ III A - III С стадій можливий тільки після оптимальної або субоптимальної циторедуктивної операції. Всі пацієнтки відзначали добру переносимість запропонованої методики. Також не спостерігали відмінностей у токсичності застосовуваних препаратів між традиційною терапією РЯ і вдосконаленою методикою із застосуванням НYРЕС.

Assessment Schedule 2.0. / T. B. Ustün, S. Chatterji, N. Kostanjsek [et al.] // Bull World Health Organ. - 2010. - Vol. 88(11) - P. 815-823.

8. Etude de la qualite de vie dans les neoplasies ovariennes: outils et enjeux / A. Bryand, Z. Hamidou, S. Paget-Bailly [et al.] // Gynecol. Obstet. Fertil. - 2015. - Vol. 43(2). - P. 151-157. 9. Hippisley-Cox J. Independent external validation of QCancer (Ovarian) / J. Hippisley-Cox, C. Coupland // Eur. J. Cancer Care (Engl). - 2013. - Vol. 22(4). - P. 559-560.

10. Pual Sugarbaker H. Management of peritoneal surface malignancy using intraperitoneal chemotherapy and cytoreductive surgery / Pual H. Sugarbaker. - The Ludann Company Grand Rapids, Michigan, USA, 1998. - 59 p.

11. Studying platinum sensitivity and resistance in high-grade serous ovarian cancer: Different models for different questions / N. G. Alkema, G. B. Wisman, A. G. van der Zee [et al.] // Drug Resist Updat. - 2016 - Vol. 24 - P. 55-69.

12. The Added Value of Analyzing Pooled Health-Related Quality of Life Data: A Review of the EORTC PROBE Initiative / E. Zikos, C. Coens, C. Quinten [et al.] // J. Natl. Cancer Inst. 2015 - Vol. 108(5) - P. 39-41.

Отримано 15.08.16 